\title{
Adaptive Internet Technology as a Tool for Flipping the Classroom to Develop Communicative Foreign Language Skills
}

\author{
https://doi.org/10.3991/ijet.v13i07.8092 \\ Olga Igorevna Shaykina $\left.{ }^{(}\right)$, Mikhail Grigoryevich Minin \\ National Research Tomsk Polytechnic University, Tomsk, Russian Federation \\ nikol_2507@mail.ru
}

\begin{abstract}
A promising method of flipped classroom technology is becoming increasingly popular among higher education teachers. Flipping the classroom is considered to be a sufficient approach for best time spreading in-class by actively engaging students during practical lessons. The article examines flipped classroom technology implementation on the grounds of adaptive online technology. A detailed algorithm of actions on the work of a studied online resource is developed. The study explores the ability of students to work under the conditions of flipping the classroom by means of adaptive learning technology empirically. Efficiency criteria of learning technology application are identified and described. Lesson planning of both experimental and control groups is shown in details. Research data demonstrate adaptive technology integration into flipped classroom method as a successful approach for higher education teachers who can develop their own style for flipping their instructions. It is established that the studied joint technologies demonstrate an efficient impact on the development of communicative skills.
\end{abstract}

Keywords-flipped classroom, adaptive learning, e-learning, Internet learning technology.

\section{Introduction}

In the $21^{\text {st }}$ century the increase of sharing knowledge and need for implementation of information communication technologies for academic purposes are pivotal. Pedagogical technologies deal with the use of the Internet to organize foreign language learning based on the open educational platforms and resources [10]. Educational information technologies are considered as theoretical and methodological justifications within the confines of the development of models, principles, systems and means of studying.

The trend is towards the reduction of foreign language teaching hours; however, with the integration of Russia into the European higher education arena the requirements for graduates are becoming more demanding. These changes represent a significant challenge because practical communication skills require an interaction not only between a teacher and students but should be aimed at future competences necessary 
for up-to-date requirements of employers. [11]. Based on our own teaching experience among the significant disadvantages of traditional English language learning the following drawbacks can be identified:

— insufficient motivation to the cognitive activity, students generally rely on direct communication with a teacher;

- increasing quantity of information limited by lesson time frame;

- difficulties in working with course books independently;

- predominance of verbal teaching methods creating premises for developing communication skills.

Some universities have found a solution to the above issues through the introduction of distance learning platforms such as Moodle, Toolkit, MOOCs but the question of integrating additional effective training tools is still unresolved [1].

The current research is intended to improve the quality of active learning in order to demonstrate that students are able to achieve the intended learning goals individually at home by means of their computers, laptops or even mobiles [7]. The most enumerated problems are successfully solved within popular recently acquired method known as flipped classroom technology. The flipped classroom refers to a type of learning that overhauls the time spent both in and out of class with a view to transferring responsibility for training from the educators to the students. It is safe to say that flipped classroom technology is regarded as teaching approach in which valuable class time is devoted to higher cognitive, more active, project-based learning where students work individually first to prepare for in-class meetings to gain a deeper understanding of the subject [5].

\section{Literature Review}

Recent research on the basis of flipping the classroom showed various productive effects of student achievements. As stated in Ref. [11] flipped classroom model was suggested and viewed from the standpoint of individual work when teaching students [11].

As for foreign researchers, stated in Ref. [8], from New York three reasons to flip the classroom were defined. The author argues that flipped classroom method (1) increases comprehension of the material; (2) increases interaction with instructor and peers; and (3) increases critical thinking as a natural part of the learning process [8]. As stated in Ref. [3] the scientists from the Netherlands explored students' study behaviour through a flipped and a regular course by means of diaries. It was found out that students' study behaviour in the flipped course did not differ from that of students in a regular course. Nevertheless, the researchers insist on further study intended to understand when and why implementing the flipped classroom is successful [3].

As stated in Ref. [4], with respect to studying the flipped classroom technology as a modern approach, the scientists made a sufficient contribution into direct application for flipped classroom technology combining it with case study method [4]. 


\section{$3 \quad$ Methodology}

Flipped classroom technology is held to imply that the teacher uses learning time to dispense information in a way that the task is performed by each student after class. This process is carried out through watching video lectures, listening to podcasts, perusing enhanced e-book content, or communication with friends in social networks. However, not only video lectures can be taken into account as the basis for flipping the classroom; any adaptive Internet resource applied for training may be used. Thus, students access online platforms and resources any time they need them. Most online tools created for academic purposes are available on tablets and mobile phones [7].

The main goal of the study is to explore the efficiency of flipped classroom implementation by means of an adaptive online resource application for the development of communication skills.

According to the raised problem, the main research methods are theoretical which include literature analysis of the studied method condition in Russia and abroad, and an empirical study including observation, questionnaires and peer review method.

\section{$4 \quad$ Initial Research}

Since the experiment is considered to be the most effective way of proving the studied issue, it was decided to check the ability of students to work empirically under the conditions of flipping the classroom using Internet learning platforms.

The participants of the study were two groups of students of elementary level, second course, a total of 30 students aged from 18 to 19 years. The experiment was conducted in the first half of the third semester on the theme "The world of work". In order to minimize the influence of external factors both groups had the same instructor. As a means of an empirical impact on the experimental group, we name it Group 1 or G1, the adaptive online resource www.goconqr.com applicable for academic purposes was used. The control group, Group 2 or G2, was taught through traditional methods such as course books, printouts and exercises. The students of both groups were given the same 50 words and word combinations in the framework of the studied theme. The participants of Group 1 trained memorizing of new vocabulary using goconqr tools. The participants of Group 2 read and translated the text followed by the exercises, and prepared for a dictation, a traditional form of control. As an intermediate control over material assimilation and memorizing new vocabulary, students were asked to compose a detailed answer to the question "What are the benefits of your future profession?" The criteria for the effectiveness of the learning process based on the flipped classroom technology were decided to determine by the following indicators:

- time-saving in the classroom;

- a number of words used when speaking;

- time spent on homework. 
Goconqr is an online educational platform adapted for creating and sharing learning content in different formats, so that the students have a possibility to carry out their educational activities. Using Goconqr tools is directed to collaborative work under the guidance of a teacher and independently from a home computer. We shall consider a step-by-step algorithm of actions on the work organization in an open educational resource goconqr.com.

Step 1. The teacher is registered on the site using e-mail or an existing account in Google or Facebook, receives the status of the administrator (admin). In addition to creating its own training content, the administrator has the right to create and delete groups of students, publish topics for discussions, comment on them, create online courses, import own resources or students' from the site.

Step 2. The administrator is able to create a nominal group of students. At this stage, he can write a greeting and upload a suitable thematic image. The group may be open or close depending on the purpose of the instructor.

Step 3. Students go through the registration procedure on the site; by clicking "invite" both instructors and students become "friends" that followed by joining students to the group. It should be noted that registration process takes no more than 10 minutes.

Step 4. With the language support of the teacher, students are encouraged to choose their own resource by clicking "create" in the upper left corner of the panel. For example, by selecting the quiz tool, team members can work out a quiz on the topic, including a variety of exercises: true/false, multiple choice, gap filling, and others. For visual effect, pictures and text images are relevant.

Step 5. Students create and upload their resources into the group, choosing "actions", then "share to a group". At this stage peer-correction method is available when participants carry out each other's tasks. The result will appear in the "analytics" section in the form of a diagram; the percentage of correctness of the passed quiz will also be shown.

Lesson planning of 2 practical lectures both of the experimental and control groups is shown in details in Table 1 . The experiment was conducted within 4 practical lectures, 8 academic hours, so that students were asked to log in before the empirical research started. After analyzing research data, the instructor offered participants of Group 2 to share their impressions from a new approach and assess its availability (quick search in different browsers, mobile version and operating quality on Android system).

\section{$5 \quad$ Findings}

Having analyzed research data, it was observed that time optimization is one of the main assessing performances of the flipped classroom technology. Taking into consideration the limited amount of in-class learning, time-saving technologies and methods available on mobile devices are of much significance now. 
Table 1. Lesson plan with flipped classroom technology implementation.

\begin{tabular}{|c|c|c|c|}
\hline \multicolumn{2}{|c|}{ Group 1} & \multicolumn{2}{|c|}{ Group 2} \\
\hline \multicolumn{2}{|c|}{ Task before the lesson: } & \multicolumn{2}{|c|}{ Task before the lesson: } \\
\hline \multicolumn{2}{|l|}{ create 10 flashcards } & \multicolumn{2}{|l|}{ read and translate the text } \\
\hline \multicolumn{2}{|c|}{ Lesson 1: } & \multicolumn{2}{|c|}{ Lesson 1: } \\
\hline stage & activity & stages & activity \\
\hline -work in pairs & sharing flashcards & -frontal teaching & preparatory task \\
\hline -peer-correction & $\begin{array}{l}\text { online format } \\
\text { correction of mistakes }\end{array}$ & -reading & $\begin{array}{l}\text { read and translate the } \\
\text { text }\end{array}$ \\
\hline -face-to-face work & $\begin{array}{l}\text { make up sentences using } \\
\text { new vocabulary on the } \\
\text { topic "applying for a } \\
\text { job" }\end{array}$ & -task for the next lesson & $\begin{array}{l}\text { gap-filling exercise after } \\
\text { the text }\end{array}$ \\
\hline -dialogues & Job interview & & \\
\hline -task for the next lesson & $\begin{array}{l}\text { make an online quiz with } \\
\text { new vocabulary }\end{array}$ & & \\
\hline \multicolumn{2}{|c|}{ Lesson 2: } & \multicolumn{2}{|c|}{ Lesson 2: } \\
\hline -panel discussion & $\begin{array}{l}\text { advantages of your } \\
\text { future profession }\end{array}$ & -work in pairs & training new vocabulary \\
\hline -frontal teaching & checking quizzes & $\begin{array}{l}\text { - training exercises after } \\
\text { the text }\end{array}$ & $\begin{array}{l}\text { matching, gap-filling, } \\
\text { true/false }\end{array}$ \\
\hline -do the quizzes & $\begin{array}{l}\text { do the quizzes created by } \\
\text { groupmates }\end{array}$ & -task for the next lesson & $\begin{array}{l}\text { choose the appropriate } \\
\text { words for a job inter- } \\
\text { view from the list }\end{array}$ \\
\hline -online assessment & $\begin{array}{l}\text { watching an estimating } \\
\text { diagram, created auto- } \\
\text { matically after perform- } \\
\text { ing a quiz }\end{array}$ & & \\
\hline - task for the next lesson & correction of mistakes & & \\
\hline
\end{tabular}

First, flipped classroom technology application allows to increase a number of lesson stages, devoting more time for communication compared with the traditional learning process. As it is seen from Table 1, only two items of Group 2 lesson plan were done whereas the students of Group 1 managed to perform more during work aimed at training communication skills. The instructor teaching Group 1 made more efficient use of their time by focusing on content that is especially challenging for students - unprepared spontaneous speech.

Second, summarizing an amount of studied words used in the final task, we shall conclude that students of Group 1 included an average of about 24 words and word combinations in active speech. The participants of Group 2 had some difficulties with defining the right word due to the purpose of the utterance. This is explained by the fact that Group 2 were initially aimed at writing a dictation turning on mechanical memory or learning words by rote.

Third, during the experiment participants of both groups fixated the time spent on their homework. Through the questionnaire method Group 1 pointed out that average execution time equals to 20 minutes. They gratefully added that a significant advantage of creating flashcards, quizzes and mind maps online is associative memoriz- 
ing (or mnemonics). Hence, they did not need to learn the words by heart. Thus, Group 1 could reproduce and use new active vocabulary effortless.

Through the results obtained it is plausible to conclude that the primary goal of flipped classroom technology efficient implementation through adaptive online technology is achieved. A promising productive approach deals not only with video lectures as basic technical tools but also appears to gain widespread use among everincreasing number of Internet resources used for educational purposes.

The following percentage ratio was identified when students shared their impressions by means of anonymous questionnaire survey:

- $100 \%$ of students highly evaluated new method of memorizing new vocabulary;

- $67 \%$ did not have any issues with surfing the site even from their mobile phones. Thus, they emphasized that doing homework became possible while travelling by bus, sitting in the park, etc.

- $86 \%$ could easily log in from any browser;

- $24 \%$ shared their resources with foreign users and found pen pals by interests;

- $81 \%$ found unusual home tasks interesting and informative.

Taking into account the percentage data, we shall say with certainty that flipped classroom technology with adaptive online resources demonstrate positive impact on the development of communication skills as well as positive emotional impact.

\section{Conclusion}

The flipped classroom technology requires remote working conditions, which may cause difficulties for students who prefer to rely on the teacher as the leading source of information for communication skills development. Students are eager to speak but the lack of active vocabulary is one of the main limiting factors to speak in a foreign language fluently. Therefore, out-class interaction should be organized in a simple way and meet the following requirement: more content is given out of class while both practice and communication training take place in a face-to-face format [2]. While preliminary research data show limited explication of possible variations covered in the present study, it makes sensible to expand comprehension of flipped classroom implementation by means of other adaptive learning technologies.

\section{$7 \quad$ Acknowledgement}

The research is carried out at Tomsk Polytechnic University within the framework of Tomsk Polytechnic University Competitiveness Enhancement Program grant.

\section{$8 \quad$ References}

[1] Aikina, T.Yu., Sumtsova, O.V., Pavlov, D.I. (2015). Implementing electronic courses based on Moodle for foreign language teaching at Russian technical universities. Interna- 
tional Journal of Emerging Technologies in Learning (iJet). Volume 10, Issue 3. pp. 58-61. https://doi.org/10.3991/ijet.v10i3.4501

[2] Bergmann J, Sams A. (2012). Flip Your Classroom: Reach Every Student in Every Class Every Day. ISTE/ASCD.

[3] Boevé, A.J., Meijer, R.R., Bosker, R.J. et al. (2016). High Educ. https://doi.org/10.1007/ s10734-016-0104-y

[4] Chua Shu Min Joanne, Fatimah Lateef. (2014). The flipped classroom: viewpoints in Asian Universities. Education in Medicine Journal, Malaysia. https://doi.org/10.5959/eimj. v6i4.316

[5] Johnson, L., Adams Becker, S., Estrada, V., Freeman, A. (2015). NMC Horizon Report > 2015 Higher Education Edition. Austin, Texas: New Media Consortium.

[6] Larson, R.C., Murray, E.M. (2008). Open educational resources for blended learning in high schools: overcoming impediments in developing countries. Journal of Asynchronous Learning Networks, Massachusetts. http://files.eric.ed.gov/fulltext/EJ837471.pdf https://doi.org/10.24059/olj.v12i1.52

[7] Marsh, D. (2012). Blended Learning. Creating learning opportunities for language learners. New York: Cambridge University Press.

[8] Marshall, H. (2013). Three reasons to flip your classroom. New York, USA. http://newsmanager.commpartners.com/tesolbeis/issues/2013-08-28/6.html

[9] Polat, E.S. (2004). Theory and practice of distance learning. Moscow: Academy.

[10] Shaykina, O.I. (2015). Blended Learning in English Language Teaching: Open Educational Resources Used for Academic Purposes in Tomsk Polytechnic University. Mediterranean Journal of Social Sciences. https://doi.org/10.5901/mjss.2015.v6n3s5p255

[11] Vulfovich, E.V. (2017). Organizatsiya samostoyatel'noj raboty po inostrannomu yazyku na osnove modeli "perevernutyj klass" (in Russian) [Organization of foreign language independent work based on the flipped classroom model]. Vysshee obrazovanie v Rossii, Moscow.

\section{Authors}

Olga Igorevna Shaykina and Mikhail Grigoryevich Minin are with National Research Tomsk Polytechnic University, Tomsk, Russian Federation.

Article submitted 10 December 2018. Resubmitted 22 March 2018. Final acceptance 25 March 2018. Final version published as submitted by the authors. 